\title{
被覆期間の違いが茶樹の生育と夏期の樹冠面温度に及ぼす影響
}

\author{
京都府農林水産技術センター農林センター* \\ 竹本哲行 ${ }^{\dagger} \cdot$ 林健
}

（2019年 4 月17日受理）

\section{Effect of the Difference in the Covering Methods on Growth of Tea Tree and the Canopy Surface Temperature in Summer Based on Thermal Images}

\author{
Tetsuyuki Takemoto and Ken Hayashi \\ Kyoto Prefectural Agriculture, Forestry and Fisheries Technology Center, \\ Agriculture and Forestry Department
}

Summary

Covering cultivation is a critically important method for high quality powdered green tea production. The covering period, once a year previously, becomes twice a year with drastically increasing demand for powdered green tea since around 2000. Therefore, there is a fear of some damage to the tea tree by decreased growth due to insufficient photosynthesis. This research was conducted for five years to examine the effect of covering periods in a year on the growth of tea shoots and the canopy surface temperature based on thermal images. As prolongation of covering period in a year, decreased growth, and higher temperature on the canopy surface in midsummer were observed, since the 2nd year of direct covering cultivation, and since the 3rd year of ceilingshelf covering cultivation, indicating that the difference in the covering methods has influences on the growth of tea tree over several years. Our results suggested possibility of detecting accumulative damage to the tea tree caused by excessive covering period, based on thermal images of the canopy surface.

Key Words : covering culture, diagnosis of tea plant, thermal image, tea plant, canopy surface temperature

キーワード : 被覆栽培, 樹体診断, 熱画像, チャ, 樹冠面温度

\section{1 緒 言}

京都府宇治地方では古く室町時代から茶栽培が行わ れ, 室町時代末期までさかのぼる「覆い下栽培」と呼ば
れる伝統的な被覆栽培手法によって，てん茶が生産され てきた。具体的には, 一番茶摘採直前の14～30日程度の 期間, 85〜 98\%の遮光条件下で一番茶を栽培する手法で, 主として一番茶のみに用いられてきた栽培である。従来 は, 毎年一番茶期のみ被覆されていたので, 茶樹は安定

T621-0806 京都府亀岡市余部町和久成 9

Corresponding author : t-takemoto82@pref.kyoto.lg.jp 
的に維持されてきたが，抹茶需要の急増に対応し， 2000 年ごろから一番茶期に加え二番茶期にも被覆することが 多くなってきた。この一番茶期と二番茶期の年間 2 回の 連続する被覆では, 樹体を光不足に置く期間が従来から 倍増するため, 樹体への悪影響が懸念されている。被覆 が茶樹に及ぼす効果を, 製茶品質の視点から見た研究 ${ }^{1 \sim 5)}$ は数多く行われ，樹体への影響を被覆の翌年まで調べた 報告 $^{6)}$ もあるが，一番茶期と二番茶期の近接した年 2 回の被覆を毎年繰り返す栽培の場合, それが茶樹体に及 ぼす経年的な影響を明確にした試験は知られていない。

また, 抹茶の急激な需要増加に対応する必要がある生 産現場では, 年間複数回の被覆で懸念される茶樹への悪 影響を未然に予防する対策が求められる。何らかの対策 を行うためには, その前提として悪影響が出始めた茶樹 を見分ける必要があるが, 現状ではそれはかなり困難で ある。

一方, 2 次元赤外線センサーによる熱画像センシング 技術の発展は近年目覚ましく，離れた場所からの熱画像 撮影によるビル外壁や電気設備の点検は日常的に行われ ている。また，この手法を植物の状態評価へ適用する試 みも多数行われ ${ }^{7 \sim 11)}$, 街路樹や果樹を含む種々の作物 で基礎的知見が得られている。チャでも, 乾燥ストレス を受けていると樹冠の温度が高くなることなどが報告さ れ, 茶樹の状態把握への可能性も指摘されている ${ }^{12,13)}$ 。 熱画像装置は, 離れた場所から茶樹樹冠面温度を測定で きるので, この方法で茶樹の状態把握が可能になれば, 過度の被覆により悪影響が出始めた茶樹を見分け，被覆 による状態悪化の程度や回復状況の評価などにも使える 可能性がある。

そこで, 棚がけ被覆栽培と直がけ被覆栽培で, 一番茶 と二番茶で年 2 回の連続被覆栽培を 5 か年間継続して実
施し, 茶樹の生育・収量と樹冠面温度に及ぼす影響を詳 しく調べ，樹冠面温度が茶樹生育状態の指標になりうる のかを検討した。

\section{2 材料および方法}

京都府農林水産技術センター農林センター茶業研究所 （標高84 m) で, 直がけ被覆については ‘やぶきた’茶 園（1973年定植, 弧状仕立てR1150), 棚がけ被覆につ いては ‘うじみどり’ 茶園（1984年定植，水平仕立て R3000）を用いた。試験期間は2011年春から2015年の 5 年間で, 一番茶期と二番茶期の 2 回, 覆い下栽培を毎年 繰り返し, 収量などの生育調査と熱画像装置による樹冠 面温度の測定を行った。なお, 直がけ被覆と棚がけ被覆 では, 現場の都合上同一品種が供試できなかったが, 供 試品種はともに京都府内の茶生産現場で使用されている 品種である。

被覆開始は, ‘やぶきた, うじみどり’ともに新芽の 1 ～ 1.5 葉開葉期とし， 各年の被覆期間などをまとめて 表 1 に示した。被覆は黒色化学繊維資材（ポリエチレ ン製）を用い, ‘やぶきた’は直がけ被覆（遮光率は 85\%), ‘うじみどり’は一段棚被覆（遮光率は92\%）と した。施肥量は 10 a当たり窒素75 kg, リン酸 $30 \mathrm{~kg}$, カ リ $24 \mathrm{~kg}$ とし, 試験規模は 1 区 $18.0 \mathrm{~m}^{2}(1.8 \mathrm{~m} \times 10 \mathrm{~m})$ の 2 反復とした。

収量と生育量の調査は, ‘やぶきた,うじみどり’とも, $20 \mathrm{~cm}$ 枠摘みにより茶芽を基部から採取し, 新芽形質と して摘芽数, 新芽長, 百芽重, 新葉数, 出開き度を調査し, 摘芽数と百芽重から理論収量を算出した。枠摘み箇所は, 各区 6 箇所とした。採取時期は, 覆い下栽培 2 年を経過 した2012年10月31日以降, 秋整枝時期, 一番茶被覆開始

表 1 被覆試験の試験区の構成および被覆実施時期

\begin{tabular}{|c|c|c|c|c|c|c|c|c|}
\hline \multicolumn{2}{|c|}{ 試験区 } & \multicolumn{2}{|c|}{ 被覆日数（日） } & \multicolumn{5}{|c|}{ 各年の被覆処理の実施期間（月/日-月/日） } \\
\hline $\begin{array}{l}\text { 被覆方法 } \\
\text { 供試品種 } \\
\end{array}$ & 処理 & $\begin{array}{l}\text { 一番 } \\
\text { 茶期 } \\
\end{array}$ & $\begin{array}{l}\text { 二番 } \\
\text { 茶期 } \\
\end{array}$ & 2011年 & 2012年 & 2013年 & 2014年 & 2015年 \\
\hline \multirow{3}{*}{$\begin{array}{l}\text { 棚がけ被覆 } \\
\text { うじみどり }\end{array}$} & 無被覆（対照） & 0 & 0 & 一 & - & - & - & - \\
\hline & 一番茶被覆 & 30 & 0 & $4 / 25-5 / 24$ & $4 / 24-5 / 24$ & $4 / 17-5 / 17$ & $4 / 17-5 / 17$ & $4 / 15-5 / 15$ \\
\hline & $\begin{array}{c}\text { 一番茶二番茶 } \\
\text { 被覆 }\end{array}$ & 30 & 20 & $\begin{array}{l}4 / 25-5 / 24 \\
7 / 7-7 / 27\end{array}$ & $\begin{array}{l}4 / 24-5 / 24 \\
6 / 27-7 / 17\end{array}$ & $\begin{array}{l}4 / 17-5 / 17 \\
6 / 27-7 / 17\end{array}$ & $\begin{array}{l}4 / 24-5 / 24 \\
6 / 19-7 / 9\end{array}$ & $\begin{array}{l}4 / 15-5 / 15 \\
6 / 18-7 / 8\end{array}$ \\
\hline \multirow{3}{*}{$\begin{array}{c}\text { 直がけ被覆 } \\
\text { やぶきた }\end{array}$} & $\begin{array}{l}\text { 無被覆 } \\
\text { (対照) }\end{array}$ & 0 & 0 & - & - & 一 & 一 & - \\
\hline & 一番茶被覆 & 30 & 0 & $4 / 26-5 / 26$ & $4 / 25-5 / 25$ & $4 / 18-5 / 18$ & $4 / 18-5 / 18$ & $4 / 20-5 / 20$ \\
\hline & $\begin{array}{c}\text { 一番茶二番茶 } \\
\text { 被覆 }\end{array}$ & 30 & 20 & $\begin{array}{l}4 / 26-5 / 26 \\
7 / 8-7 / 28\end{array}$ & $\begin{array}{l}4 / 25-5 / 25 \\
6 / 28-7 / 18\end{array}$ & $\begin{array}{l}4 / 18-5 / 18 \\
6 / 27-7 / 17\end{array}$ & $\begin{array}{l}4 / 25-5 / 25 \\
6 / 19-7 / 9\end{array}$ & $\begin{array}{l}4 / 20-5 / 20 \\
6 / 24-7 / 14\end{array}$ \\
\hline
\end{tabular}


30日後，二番茶被覆開始20日後を目安に行い，2015年ま で継続した。

樹冠面温度の計測は，赤外線サーモグラフィー（日本 アビオニクス社製：TH6300R）を用いた。測定は快晴 日の11〜13時の間に行い，地上 $170 \mathrm{~cm}$ の位置から南北 うねの南端から北方向に，サーモグラフィーをうねと平 行に構えた後， $30^{\circ}$ 下方を俯瞰して，およそ $1.5 \mathrm{~m}$ 先の樹 冠面を撮影した。熱画像から樹冠面温度の数値は, 熱画 像解析ソフトIC_Report Duo Vision Standard-Version 1.01.01（TROTEC GmbH \& CO. KG.) を用いて各区 6 箇所の温度值を無作為に抽出し，平均することにより算 出した。

\section{3 結 果}

\section{1 棚がけ被覆試験における生育量調査}

2012年秋芽の理論収量は一番茶二番茶被覆区で有意に 低かった。収量構成要素について調査したところ，新芽 長に有意差は認められず，摘芽数が一番茶二番茶被覆区 で有意に低く, 新葉数は有意に多かった（表 2 上段）。 次茶期となる2013年の一番茶芽の収量構成要素について 調査したところ，摘芽数に有意差は認められなかったこ とから前年秋の芽数が少なかったものの, 芽当たりの新
葉数が多かったため, 相殺された結果によると考えられ た。新芽長, 百芽重, 新葉数に有意差は認められず, 理 論収量にも有意差は認められなかった（表 3 上段）。

2013年秋芽の理論収量は一番茶被覆区，一番茶二番茶 被覆区で有意に低かった。収量構成要素について調查し たところ，新芽長，百芽重，新葉数は一番茶被覆区，一 番茶二番茶被覆区で有意に低く, 摘芽数は無被覆区と一 番茶二番茶被覆区との間で有意差が認められた（表 5 上 段)。次茶期となる2014年の一番茶芽の収量構成要素に ついて調査したところ, 摘芽数が一番茶被覆区，一番茶 二番茶被覆区で有意に低く, 理論収量も有意に低かった (表 6 上段)。

2014年秋芽の理論収量は一番茶被覆区と一番茶二番茶 被覆区との間で有意差が認められた。収量構成要素につ いて調查したところ, 新芽長, 百芽重, 新葉数, 摘芽数 については処理区間で有意差が認められなかった（表 8 上段)。次茶期となる2015年の一番茶芽の収量構成要素 について調査したところ, 摘芽数, 新芽長について有意 差は認められなかったが, 百芽重は一番茶被覆区，一番 茶二番茶被覆区で有意に低く, 新葉数は一番茶二番茶被 覆区で有意に低かった。理論収量は一番茶被覆区，一番 茶二番茶被覆区で有意に低かった（表 9 上段）。

表 2 被覆処理が被覆処理二年目（2012）の秋芽の生育に及ぼす影響

\begin{tabular}{|c|c|c|c|c|c|c|c|}
\hline \multicolumn{2}{|c|}{$\begin{array}{l}\text { 試験区 } \\
\end{array}$} & \multirow[b]{2}{*}{$\begin{array}{c}\text { 新芽長 } \\
(\mathrm{cm})\end{array}$} & \multirow[b]{2}{*}{$\begin{array}{c}\text { 百芽重 } \\
(\mathrm{g})\end{array}$} & \multirow[b]{2}{*}{$\begin{array}{c}\text { 新葉数 } \\
\text { (枚) }\end{array}$} & \multirow[b]{2}{*}{$\begin{array}{c}\text { 出開き度 } \\
(\%)\end{array}$} & \multirow[b]{2}{*}{$\begin{array}{c}\text { 摘芽数 } \\
\text { (本) }\end{array}$} & \multirow[b]{2}{*}{$\begin{array}{l}\text { 理論収量 } \\
(\mathrm{kg} / 10 \mathrm{a})\end{array}$} \\
\hline $\begin{array}{c}\text { 被覆方法 } \\
\text { 供試品種 } \\
\text { 調査の年/月/日 }\end{array}$ & 処理 & & & & & & \\
\hline 棚がけ被覆 & 無被覆（対照） & $3.5 \mathrm{a}^{*}$ & $58.0 \mathrm{a}$ & $4.3 \mathrm{a}$ & $81.3 \mathrm{a}$ & $59.5 \mathrm{c}$ & $851.8 \mathrm{c}$ \\
\hline うじみどり & 一番茶被覆 & $3.8 \mathrm{a}$ & $63.3 \mathrm{ab}$ & $4.4 \mathrm{a}$ & $81.8 \mathrm{a}$ & $45.0 \mathrm{~b}$ & $691.3 \mathrm{~b}$ \\
\hline $2012 / 10 / 31$ & 一番茶二番茶被覆 & $3.8 \mathrm{a}$ & $73.1 \mathrm{~b}$ & $6.0 \mathrm{~b}$ & $100.0 \mathrm{~b}$ & $24.0 \mathrm{a}$ & $437.7 \mathrm{a}$ \\
\hline 直がけ被覆 & 無被覆（対照） & $5.1 \mathrm{~b}$ & $96.8 \mathrm{~b}$ & $4.7 \mathrm{~b}$ & $89.0 \mathrm{a}$ & $39.0 \mathrm{a}$ & $936.1 \mathrm{~b}$ \\
\hline やぶきた & 一番茶被覆 & $4.1 \mathrm{~b}$ & $93.7 \mathrm{~b}$ & $3.8 \mathrm{a}$ & $60.6 \mathrm{a}$ & $31.7 \mathrm{a}$ & $742.7 \mathrm{a}$ \\
\hline $2012 / 10 / 31$ & 一番茶二番茶被覆 & $3.5 \mathrm{a}$ & $72.7 \mathrm{a}$ & $3.8 \mathrm{a}$ & $73.0 \mathrm{a}$ & $36.3 \mathrm{a}$ & $637.8 \mathrm{a}$ \\
\hline
\end{tabular}

注）＊印：2 重線で区切られた同一被覆方法での処理区には異なる英文字間に $5 \%$ 水準で有意差があることを示す (TukeyのHSD検定、出開き度のみSteel-Dwass法による検定)

表 3 被覆処理が被覆処理三年目（2013）の一番茶の生育に及ぼす影響

\begin{tabular}{|c|c|c|c|c|c|c|c|}
\hline \multicolumn{2}{|c|}{ 試験区 } & \multirow[b]{2}{*}{$\begin{array}{c}\text { 新芽長 } \\
(\mathrm{cm})\end{array}$} & \multirow[b]{2}{*}{$\begin{array}{c}\text { 百芽重 } \\
(\mathrm{g})\end{array}$} & \multirow[b]{2}{*}{$\begin{array}{l}\text { 新葉数 } \\
\text { (枚) }\end{array}$} & \multirow[b]{2}{*}{$\begin{array}{c}\text { 出開き度 } \\
(\%)\end{array}$} & \multirow[b]{2}{*}{$\begin{array}{l}\text { 摘芽数 } \\
\text { (本) }\end{array}$} & \multirow[b]{2}{*}{$\begin{array}{l}\text { 理論収量 } \\
(\mathrm{kg} / 10 \mathrm{a})\end{array}$} \\
\hline $\begin{array}{c}\text { 被覆方法 } \\
\text { 調査の年/月/日 }\end{array}$ & 処理 & & & & & & \\
\hline 棚がけ被覆 & 無被覆（対照） & $1.8 \mathrm{a}^{*}$ & $40.9 \mathrm{a}$ & $2.9 \mathrm{a}$ & $64.8 \mathrm{a}$ & $64.7 \mathrm{a}$ & $650.7 \mathrm{a}$ \\
\hline うじみどり & 一番茶被覆 & $2.0 \mathrm{a}$ & $38.8 \mathrm{a}$ & $3.0 \mathrm{a}$ & $96.0 \mathrm{~b}$ & $60.0 \mathrm{a}$ & $573.3 \mathrm{a}$ \\
\hline $2013 / 5 / 17$ & 一番茶二番茶被覆 & $2.0 \mathrm{a}$ & $42.4 \mathrm{a}$ & $3.1 \mathrm{a}$ & $99.7 \mathrm{~b}$ & $50.8 \mathrm{a}$ & $536.4 \mathrm{a}$ \\
\hline "直がけ被覆 & 無被覆（対照） & $3.1 \mathrm{a}$ & $44.4 \mathrm{a}$ & $3.1 \mathrm{~b}$ & $92.5 \mathrm{a}$ & $76.8 \mathrm{~b}$ & $852.9 \mathrm{~b}$ \\
\hline やぶきた & 一番茶被覆 & $2.9 \mathrm{a}$ & $51.7 \mathrm{a}$ & $2.7 \mathrm{a}$ & $95.2 \mathrm{a}$ & $57.7 \mathrm{a}$ & $744.7 \mathrm{ab}$ \\
\hline $2013 / 5 / 18$ & 一番茶二番茶被覆 & $2.5 \mathrm{a}$ & $44.7 \mathrm{a}$ & $2.6 \mathrm{a}$ & $96.7 \mathrm{a}$ & $50.2 \mathrm{a}$ & $560.5 \mathrm{a}$ \\
\hline
\end{tabular}


表 4 被覆処理が被覆処理三年目（2013）の二番茶の生育に及ぼす影響

\begin{tabular}{|c|c|c|c|c|c|c|c|}
\hline \multicolumn{2}{|c|}{ 試験区 } & \multirow[b]{2}{*}{$\begin{array}{c}\text { 新芽長 } \\
(\mathrm{cm})\end{array}$} & \multirow{2}{*}{$\begin{array}{c}\text { 百芽重 } \\
\text { (g) }\end{array}$} & \multirow{2}{*}{$\begin{array}{c}\text { 新葉数 } \\
\text { (枚) }\end{array}$} & \multirow{2}{*}{$\begin{array}{c}\text { 出開き度 } \\
(\%)\end{array}$} & \multirow{2}{*}{$\begin{array}{c}\text { 摘芽数 } \\
\text { (本) }\end{array}$} & \multirow{2}{*}{$\begin{array}{l}\text { 理論収量 } \\
(\mathrm{kg} / 10 \mathrm{a})\end{array}$} \\
\hline $\begin{array}{c}\text { 被覆方法 } \\
\text { 調査の年/月/日 }\end{array}$ & 処理 & & & & & & \\
\hline \multirow{3}{*}{$\begin{array}{c}\text { 棚がけ被覆うじみど } \\
\text { り2013/7/17 }\end{array}$} & 無被覆（対照） & $3.2 \mathrm{~b}^{*}$ & $33.8 \mathrm{a}$ & $3.3 \mathrm{c}$ & $62.5 \mathrm{a}$ & $83.3 \mathrm{c}$ & $696.8 \mathrm{c}$ \\
\hline & 一番茶被覆 & $2.3 \mathrm{a}$ & $36.3 \mathrm{a}$ & $3.1 \mathrm{~b}$ & 64.3 a & $51.8 \mathrm{~b}$ & $568.5 \mathrm{~b}$ \\
\hline & 一番茶二番茶被覆 & $2.1 \mathrm{a}$ & $33.7 \mathrm{a}$ & $2.7 \mathrm{a}$ & $87.0 \mathrm{~b}$ & $37.2 \mathrm{a}$ & $379.8 \mathrm{a}$ \\
\hline 直がけ被覆 & 無被覆（対照） & $2.8 \mathrm{a}$ & $33.0 \mathrm{a}$ & $2.7 \mathrm{a}$ & $50.1 \mathrm{a}$ & $58.0 \mathrm{a}$ & $477.8 \mathrm{~b}$ \\
\hline やぶきた & 一番茶被覆 & $2.2 \mathrm{a}$ & $30.7 \mathrm{a}$ & $2.9 \mathrm{a}$ & $52.0 \mathrm{a}$ & $46.0 \mathrm{a}$ & $353.5 \mathrm{a}$ \\
\hline $2013 / 7 / 17$ & 一番茶二番茶被覆 & $2.1 \mathrm{a}$ & $32.2 \mathrm{a}$ & $3.0 \mathrm{a}$ & $99.7 \mathrm{~b}$ & $44.8 \mathrm{a}$ & $360.9 \mathrm{a}$ \\
\hline
\end{tabular}

注） *印表 2 と同じ

表 5 被覆処理が被覆処理三年目（2013）の秋芽の生育に及ぼす影響

\begin{tabular}{|c|c|c|c|c|c|c|c|}
\hline \multicolumn{2}{|c|}{ 試験区 } & \multirow[b]{2}{*}{$\begin{array}{l}\text { 新芽長 } \\
(\mathrm{cm})\end{array}$} & \multirow{2}{*}{$\begin{array}{c}\text { 百芽重 } \\
(\mathrm{g})\end{array}$} & \multirow{2}{*}{$\begin{array}{l}\text { 新葉数 } \\
\text { (枚) }\end{array}$} & \multirow{2}{*}{$\begin{array}{c}\text { 出開き度 } \\
(\%)\end{array}$} & \multirow{2}{*}{$\begin{array}{l}\text { 摘芽数 } \\
\text { (本) }\end{array}$} & \multirow{2}{*}{$\begin{array}{l}\text { 理論収量 } \\
(\mathrm{kg} / 10 \mathrm{a})\end{array}$} \\
\hline $\begin{array}{c}\text { 被覆方法 } \\
\text { 調查の年/月/日 } \\
\end{array}$ & 処理 & & & & & & \\
\hline 棚がけ被覆 & 無被覆（対照） & $3.6 \mathrm{~b}^{*}$ & $53.4 \mathrm{~b}$ & $3.9 \mathrm{~b}$ & $78.2 \mathrm{a}$ & $93.7 \mathrm{~b}$ & $1248.3 \mathrm{~b}$ \\
\hline うじみどり & 一番茶被覆 & $2.8 \mathrm{a}$ & $46.2 \mathrm{a}$ & $3.7 \mathrm{a}$ & $82.5 \mathrm{a}$ & $75.2 \mathrm{ab}$ & $870.4 \mathrm{a}$ \\
\hline $2013 / 10 / 29$ & 一番茶二番茶被覆 & $2.5 \mathrm{a}$ & $41.6 \mathrm{a}$ & $3.6 \mathrm{a}$ & $78.0 \mathrm{a}$ & $70.8 \mathrm{a}$ & $728.1 \mathrm{a}$ \\
\hline 直がけ被覆 & 無被覆（対照） & $4.2 \mathrm{~b}$ & $67.8 \mathrm{~b}$ & $3.6 \mathrm{~b}$ & $93.5 \mathrm{a}$ & $65.5 \mathrm{a}$ & $1097.5 \mathrm{~b}$ \\
\hline やぶきた & 一番茶被覆 & $2.8 \mathrm{a}$ & $47.9 \mathrm{a}$ & $3.2 \mathrm{~b}$ & $90.8 \mathrm{a}$ & $62.3 \mathrm{a}$ & $750.8 \mathrm{a}$ \\
\hline $2013 / 10 / 28$ & 一番茶二番茶被覆 & $2.3 \mathrm{a}$ & $45.0 \mathrm{a}$ & $3.0 \mathrm{a}$ & $88.9 \mathrm{a}$ & $60.3 \mathrm{a}$ & $682.6 \mathrm{a}$ \\
\hline
\end{tabular}

表 6 被覆処理が被覆処理四年目（2014）の一番茶の生育に及ぼす影響

\begin{tabular}{|c|c|c|c|c|c|c|c|}
\hline \multicolumn{2}{|c|}{ 試験区 } & \multirow[b]{2}{*}{$\begin{array}{c}\text { 新芽長 } \\
(\mathrm{cm})\end{array}$} & \multirow{2}{*}{$\begin{array}{c}\text { 百芽重 } \\
(\mathrm{g})\end{array}$} & \multirow{2}{*}{$\begin{array}{l}\text { 新葉数 } \\
\text { (枚) }\end{array}$} & \multirow{2}{*}{$\begin{array}{c}\text { 出開き度 } \\
(\%)\end{array}$} & \multirow{2}{*}{$\begin{array}{c}\text { 摘芽数 } \\
\text { (本) }\end{array}$} & \multirow{2}{*}{$\begin{array}{l}\text { 理論収量 } \\
(\mathrm{kg} / 10 \mathrm{a})\end{array}$} \\
\hline $\begin{array}{c}\text { 被覆方法 } \\
\text { 調査の年/月/日 }\end{array}$ & 処理 & & & & & & \\
\hline 棚がけ被覆 & 無被覆（対照） & $4.5 \mathrm{a}^{*}$ & $73.5 \mathrm{a}$ & $3.2 \mathrm{a}$ & $83.6 \mathrm{a}$ & $62.0 \mathrm{~b}$ & $1139.0 \mathrm{~b}$ \\
\hline うじみどり & 一番茶被覆 & $3.9 \mathrm{a}$ & $72.0 \mathrm{a}$ & $3.3 \mathrm{a}$ & $89.4 \mathrm{a}$ & $38.0 \mathrm{a}$ & $684.0 \mathrm{a}$ \\
\hline $2014 / 5 / 17$ & 一番茶二番茶被覆 & $4.0 \mathrm{a}$ & $78.2 \mathrm{a}$ & $3.4 \mathrm{a}$ & $90.3 \mathrm{a}$ & $35.0 \mathrm{a}$ & $684.0 \mathrm{a}$ \\
\hline 直がけ被覆 & 無被覆（対照） & $5.6 \mathrm{a}$ & $70.8 \mathrm{a}$ & $3.3 \mathrm{a}$ & $94.1 \mathrm{a}$ & $57.3 \mathrm{~b}$ & $1014.0 \mathrm{~b}$ \\
\hline やぶきた & 一番茶被覆 & $4.6 \mathrm{a}$ & $67.2 \mathrm{a}$ & $3.1 \mathrm{a}$ & $86.2 \mathrm{a}$ & $44.0 \mathrm{a}$ & $739.0 \mathrm{ab}$ \\
\hline $2014 / 5 / 18$ & 一番茶二番茶被覆 & $4.6 \mathrm{a}$ & $68.1 \mathrm{a}$ & $3.1 \mathrm{a}$ & $90.6 \mathrm{a}$ & $38.0 \mathrm{a}$ & $647.0 \mathrm{a}$ \\
\hline
\end{tabular}

表 7 被覆処理が被覆処理四年目（2014）の二番茶の生育に及ぼす影響

\begin{tabular}{|c|c|c|c|c|c|c|c|}
\hline \multicolumn{2}{|c|}{ 試験区 } & \multirow[b]{2}{*}{$\begin{array}{l}\text { 新芽長 } \\
(\mathrm{cm})\end{array}$} & \multirow[b]{2}{*}{$\begin{array}{c}\text { 百芽重 } \\
(\mathrm{g})\end{array}$} & \multirow[b]{2}{*}{$\begin{array}{l}\text { 新葉数 } \\
\text { (枚) }\end{array}$} & \multirow[b]{2}{*}{$\begin{array}{c}\text { 出開き度 } \\
(\%)\end{array}$} & \multirow[b]{2}{*}{$\begin{array}{l}\text { 摘芽数 } \\
\text { (本) }\end{array}$} & \multirow[b]{2}{*}{$\begin{array}{l}\text { 理論収量 } \\
(\mathrm{kg} / 10 \mathrm{a})\end{array}$} \\
\hline $\begin{array}{c}\text { 被覆方法 } \\
\text { 調查の年/月/日 } \\
\end{array}$ & 処理 & & & & & & \\
\hline 棚がけ被覆 & $\begin{array}{l}\text { 無被覆（対照） } \\
\end{array}$ & $4.5 \mathrm{~b}^{*}$ & $67.1 \mathrm{ab}$ & $3.4 \mathrm{~b}$ & $90.7 \mathrm{~b}$ & $46.7 \mathrm{a}$ & $783.4 \mathrm{ab}$ \\
\hline うじみどり & 一番茶被覆 & $4.4 \mathrm{~b}$ & $74.5 \mathrm{~b}$ & $3.5 \mathrm{~b}$ & $91.6 \mathrm{~b}$ & $52.2 \mathrm{a}$ & $971.9 \mathrm{~b}$ \\
\hline $2014 / 7 / 9$ & 一番茶二番茶被覆 & $3.1 \mathrm{a}$ & $49.9 \mathrm{a}$ & $3.1 \mathrm{a}$ & $60.2 \mathrm{a}$ & $46.7 \mathrm{a}$ & $581.6 \mathrm{a}$ \\
\hline 直がけ被覆 & 無被覆（対照） & $1.9 \mathrm{a}$ & $34.3 \mathrm{a}$ & $2.6 \mathrm{a}$ & $81.7 \mathrm{a}$ & $57.3 \mathrm{a}$ & $491.4 \mathrm{a}$ \\
\hline やぶきた & 一番茶被覆 & $1.6 \mathrm{a}$ & $27.3 \mathrm{a}$ & $2.4 \mathrm{a}$ & $70.4 \mathrm{a}$ & $63.7 \mathrm{a}$ & $433.8 \mathrm{a}$ \\
\hline $2014 / 7 / 9$ & 一番茶二番茶被覆 & $2.1 \mathrm{a}$ & $30.6 \mathrm{a}$ & $2.6 \mathrm{a}$ & $85.3 \mathrm{a}$ & $46.5 \mathrm{a}$ & $355.7 \mathrm{a}$ \\
\hline
\end{tabular}

注）*印 表 2 と同じ

表 8 被覆処理が被覆処理四年目（2014）の秋芽の生育に及ぼす影響

\begin{tabular}{|c|c|c|c|c|c|c|c|}
\hline \multicolumn{2}{|c|}{ 試験区 } & \multirow[b]{2}{*}{$\begin{array}{l}\text { 新芽長 } \\
(\mathrm{cm})\end{array}$} & \multirow[b]{2}{*}{$\begin{array}{c}\text { 百芽重 } \\
(\mathrm{g})\end{array}$} & \multirow[b]{2}{*}{$\begin{array}{l}\text { 新葉数 } \\
\text { (枚) }\end{array}$} & \multirow{2}{*}{$\begin{array}{c}\text { 出開き度 } \\
(\%)\end{array}$} & \multirow[b]{2}{*}{$\begin{array}{l}\text { 摘芽数 } \\
\text { (本) }\end{array}$} & \multirow{2}{*}{$\begin{array}{l}\text { 理論収量 } \\
(\mathrm{kg} / 10 \mathrm{a})\end{array}$} \\
\hline $\begin{array}{c}\text { 被覆方法 } \\
\text { 調査の年/月/日 }\end{array}$ & 処理 & & & & & & \\
\hline 棚がけ被覆 & 無被覆（対照） & $4.1 \mathrm{a}^{*}$ & $82.5 \mathrm{a}$ & $3.7 \mathrm{a}$ & $80.9 \mathrm{~b}$ & $51.0 \mathrm{a}$ & $1056.5 \mathrm{ab}$ \\
\hline うじみどり & 一番茶被覆 & $3.6 \mathrm{a}$ & $74.2 \mathrm{a}$ & $3.6 \mathrm{a}$ & $79.2 \mathrm{~b}$ & $63.7 \mathrm{a}$ & $1163.0 \mathrm{~b}$ \\
\hline $2014 / 10 / 28$ & 一番茶二番茶被覆 & $3.3 \mathrm{a}$ & $63.8 \mathrm{a}$ & $3.5 \mathrm{a}$ & $51.9 \mathrm{a}$ & $47.8 \mathrm{a}$ & $748.1 \mathrm{a}$ \\
\hline 直がけ被覆 & 無被覆（対照） & $3.3 \mathrm{a}$ & $66.5 \mathrm{a}$ & $2.9 \mathrm{a}$ & $61.3 \mathrm{a}$ & $59.0 \mathrm{~b}$ & $955.5 \mathrm{~b}$ \\
\hline やぶきた & 一番茶被覆 & $3.1 \mathrm{a}$ & $66.7 \mathrm{a}$ & $2.7 \mathrm{a}$ & $48.3 \mathrm{a}$ & $37.5 \mathrm{a}$ & $630.9 \mathrm{a}$ \\
\hline $2014 / 10 / 28$ & 一番茶二番茶被覆 & $2.5 \mathrm{a}$ & $56.2 \mathrm{a}$ & $2.7 \mathrm{a}$ & $39.6 \mathrm{a}$ & $46.8 \mathrm{ab}$ & $633.5 \mathrm{a}$ \\
\hline
\end{tabular}

注）*印 表 2 と同じ 
表 9 被覆処理が被覆処理五年目（2015）の一番茶の生育に及ぼす影響

\begin{tabular}{|c|c|c|c|c|c|c|c|}
\hline \multicolumn{2}{|c|}{ 試験区 } & \multirow[b]{2}{*}{$\begin{array}{c}\text { 新芽長 } \\
(\mathrm{cm})\end{array}$} & \multirow{2}{*}{$\begin{array}{l}\text { 百芽重 } \\
(\mathrm{g})\end{array}$} & \multirow{2}{*}{$\begin{array}{l}\text { 新葉数 } \\
\text { (枚) }\end{array}$} & \multirow{2}{*}{$\begin{array}{c}\text { 出開き度 } \\
(\%)\end{array}$} & \multirow{2}{*}{$\begin{array}{c}\text { 摘芽数 } \\
\text { (本) }\end{array}$} & \multirow{2}{*}{$\begin{array}{l}\text { 理論収量 } \\
(\mathrm{kg} / 10 \mathrm{a})\end{array}$} \\
\hline $\begin{array}{c}\text { 被覆方法 } \\
\text { 調査の年/月/日 }\end{array}$ & 処理 & & & & & & \\
\hline 棚がけ被覆 & 無被覆（対照） & $6.5 \mathrm{a}^{*}$ & $108.5 \mathrm{~b}$ & $3.4 \mathrm{~b}$ & $91.3 \mathrm{a}$ & $66.6 \mathrm{a}$ & $1807.0 \mathrm{~b}$ \\
\hline うじみどり & 一番茶被覆 & $3.2 \mathrm{a}$ & 81.9 a & $3.1 \mathrm{~b}$ & $93.3 \mathrm{a}$ & $50.4 \mathrm{a}$ & $1033.0 \mathrm{a}$ \\
\hline $2015 / 5 / 15$ & 一番茶二番茶被覆 & $4.9 \mathrm{a}$ & $69.8 \mathrm{a}$ & $2.5 \mathrm{a}$ & $87.7 \mathrm{a}$ & $55.3 \mathrm{a}$ & $965.9 \mathrm{a}$ \\
\hline 直がけ被覆 & 無被覆（対照） & $6.2 \mathrm{~b}$ & $117.6 \mathrm{~b}$ & $3.1 \mathrm{~b}$ & $89.2 \mathrm{a}$ & $55.5 \mathrm{a}$ & $1631.3 \mathrm{c}$ \\
\hline やぶきた & 一番茶被覆 & $5.6 \mathrm{~b}$ & $104.2 \mathrm{~b}$ & $2.9 \mathrm{~b}$ & $81.7 \mathrm{a}$ & $48.8 \mathrm{a}$ & $1271.5 \mathrm{~b}$ \\
\hline $2015 / 5 / 20$ & 一番茶二番茶被覆 & $2.8 \mathrm{a}$ & $78.3 \mathrm{a}$ & $2.6 \mathrm{a}$ & $83.5 \mathrm{a}$ & $48.8 \mathrm{a}$ & $955.5 \mathrm{a}$ \\
\hline
\end{tabular}

\section{2 棚がけ被覆試験における樹冠面温度の 5 年 間の推移}

棚がけ被覆試験において，被覆開始 1 年目となる2011 年の樹冠面温度は，10月11日では，無被覆区と一番茶被 覆区との間で有意差が認められ，それ以外の時期におい ては，処理区間での有意差は認められなかった（図 1 )。 被覆開始 2 年目となる 2012 年の樹冠面温度は, 処理区間 での傾向が判然としなかった。7月17日では一番茶二番 茶被覆区で有意に高く，7月27日，8月17日では無被覆 区と一番茶二番茶被覆区との間で有意差が認められ，一 番茶二番茶被覆区で有意に高く，8月 1 日，8月 9 日， 10月16日では一番茶二番茶被覆区で有意に低く，9月 7 日，9月25日では処理区間での有意差は認められなかっ た（図 2 )。 3 年目の被覆を終了した2013年の樹冠面温 度は，被覆区で高い傾向が認められた。 8 月 2 日，8月 7 日，9月 6 日，10月 4 日では，無被覆区と比べて一番 茶被覆区，一番茶二番茶被覆区が有意に高く，8月21日 では，無被覆区と一番茶二番茶被覆区との間で有意差が あり，一番茶二番茶被覆区で高かった。10月10日では, 一番茶被覆区が有意に高かった。 7 月 23 日， 7 月30日，

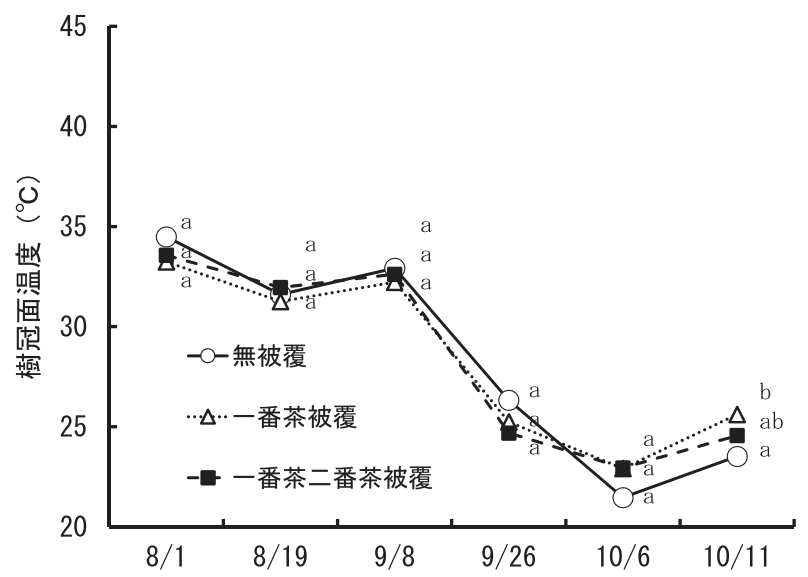

図 1 棚がけ被覆処理が2011年（一年目）の樹冠面温度に 及ぼす影響

注：異英文字間で $5 \%$ 水準で有意差があることを示す（TukeyのHSD検定）
9 月20日では，処理区間での有意差は認められなかった (図 3 )。被覆開始 4 年目の樹冠面温度は, 被覆区で高い 傾向が認められた。7月25日，7月31日，8月13日， 8 月19日，9月 2 日，9月11日では，無被覆区と比べて一 番茶被覆区，一番茶二番茶被覆区で有意に高く， 7 月 12 日，9月25日では，無被覆区と一番茶被覆区との間で有 意差が認められ，一番茶被覆区が高かった。10月15日に は無被覆区と一番茶二番茶被覆区との間で有意差が認め られ，一番茶二番茶被覆区で高かった。10月 8 日に処理 区間で有意差は認められなかった（図 4 ）。

\section{3 直がけ被覆試験における生育量調査}

2012年秋芽の理論収量は一番茶被覆区，一番茶二番茶 被覆区で有意に低かった。収量構成要素について調査し たところ, 新芽長, 百芽重は一番茶二番茶被覆区におい て有意に低かった。新葉数は一番茶被覆区, 一番茶二番 茶被覆区で有意に低かった。摘芽数には処理区間で有意 差は認められなかった（表 2 下段）。次茶期となる2013 年の一番茶芽の収量構成要素について調査したところ, 新芽長, 百芽重については有意差が認められず, 新葉数,

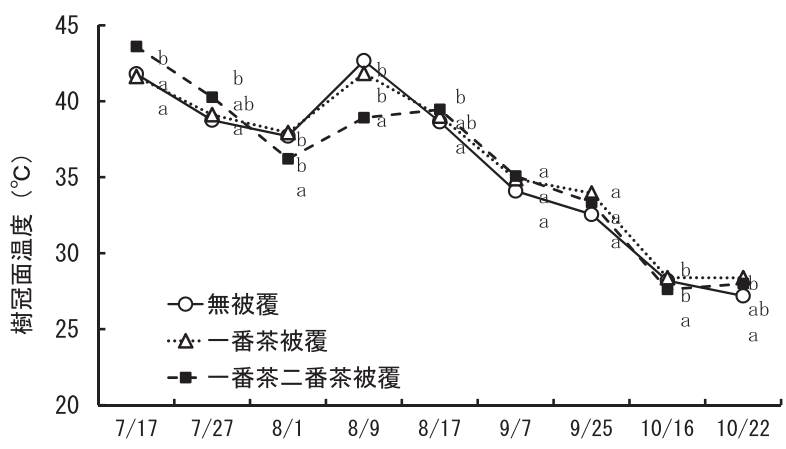

図 2 棚がけ被覆処理が2012年（二年目）の樹冠面温度に 及ぼす影響

注 : 異英文字間で $5 \%$ 水準で有意差があることを示す（TukeyのHSD検定） 


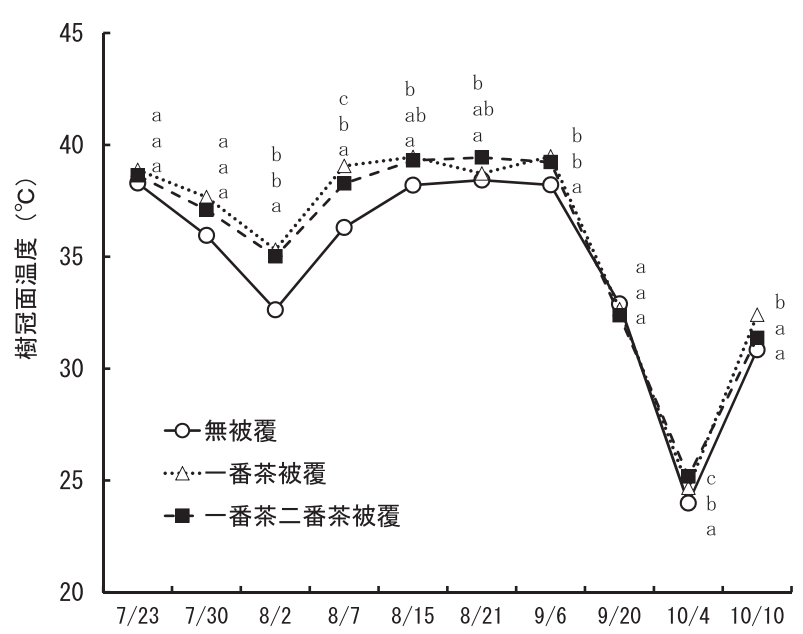

図 3 棚がけ被覆処理が2013年（三年目）の樹冠面温度に 及ぼす影響

注：異英文字間で $5 \%$ 水準で有意差があることを示す（TukeyのHSD検定）

摘芽数については一番茶被覆区，一番茶二番茶被覆区で 有意に低かったが，被覆区間において有意差は認められ なかった。理論収量は無被覆区と一番茶二番茶被覆区で 有意差が認められた（表 3 下段）。

2013年秋芽の理論収量は一番茶被覆区，一番茶二番茶 被覆区において有意に低かったが，被覆区間で有意差は 認められなかった。収量構成要素について調査したとこ ろ，新芽長，百芽重は一番茶被覆区，一番茶二番茶被覆 区に打いて有意に低く，新葉数は一番茶二番茶被覆区に おいて有意に低かった。摘芽数に有意差は認められなか った（表 5 下段）。次茶期となる2014年の一番茶の収量 構成要素を調査したところ，新芽長，百芽重，新葉数に 有意差は認められなかったが, 摘芽数は一番茶被覆区, 一番茶二番茶被覆区で有意に低く，被覆区間では有意差 は認められなかった。理論収量には無被覆区と一番茶二 番茶被覆区との間で有意差が認められた（表 6 下段）。

2014年の秋芽の理論収量は一番茶被覆区，一番茶二番 茶被覆区で有意に低かった。収量構成要素について調査 したところ, 新芽長, 百芽重, 新葉数については有意差 は認められなかったが，摘芽数については無被覆区と一 番茶被覆区との間で有意差が認められた（表 8 下段）。 次茶期となる2015年の一番茶について収量構成要素を調 查したところ, 摘芽数に有意差は認められなかったが, 新芽長，百芽重，新葉数について一番茶二番茶被覆区で 有意に低く，理論収量は無被覆区で最も多く，一番茶二 番茶被覆区で最も少なく，三処理区間でそれぞれ有意差 があった（表 9 下段）。

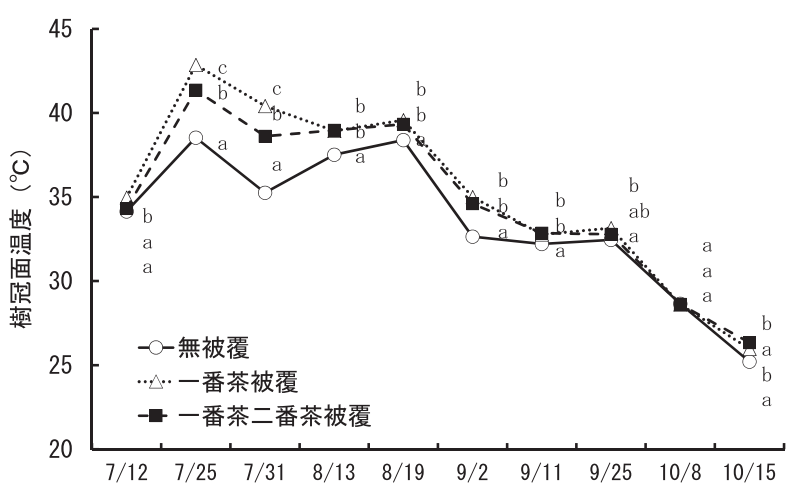

図 4 棚がけ被覆処理が2014年（四年目）の樹冠面温度に 及ぼす影響

注：異英文字間で $5 \%$ 水準で有意差があることを示す（TukeyのHSD検定）

\section{4 直がけ被覆試験における樹冠面温度の 5 年 間の推移}

直がけ被覆園において, 被覆開始 1 年目となる2011年 の樹冠面温度は，9月28日では，無被覆区と一番茶二番 茶被覆区との間で有意差が認められ，それ以外の時期に おいては，処理区間での有意差は認められなかった（図 $5)$ 。

被覆 2 年目となる2012年の樹冠面温度は, 8 月 17 日, 9 月 7 日では，無被覆区と一番茶二番茶被覆区との間で 有意差が認められ，一番茶二番茶被覆区で高く，9月25 日では，一番茶被覆区，一番茶二番茶被覆区が有意に高 かった。 7 月18日， 7 月27日， 8 月 9 日，10月16日， 10 月22日において処理区間での有意差は認められなかった (図 6 )。

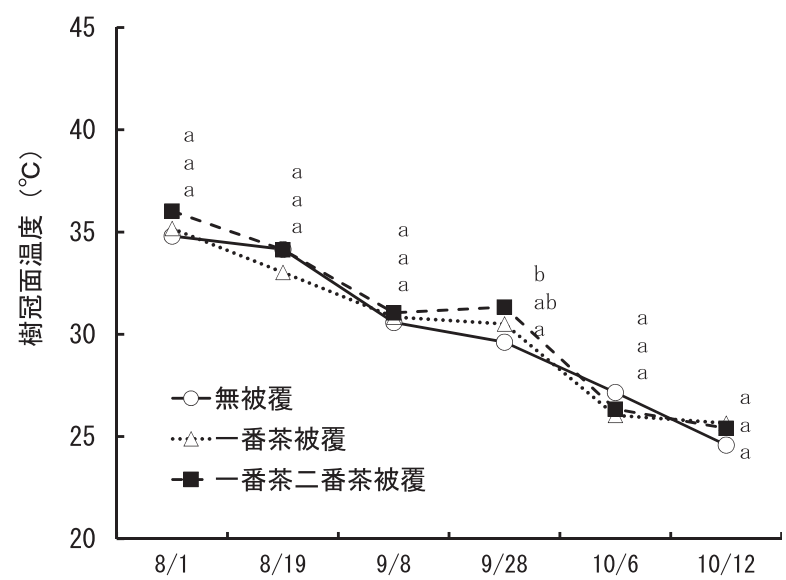

図 5 直がけ被覆処理が2011年（一年目）の樹冠面温度に 及ぼす影響

注：異英文字間で $5 \%$ 水準で有意差があることを示す（TukeyのHSD検定） 


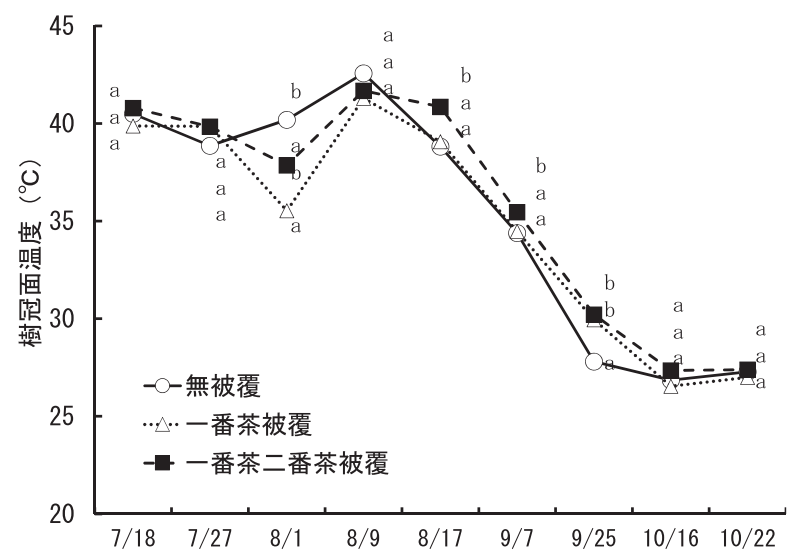

図 6 直がけ被覆処理が2012年（二年目）の樹冠面温度に 及ぼす影響

注：異英文字間で $5 \%$ 水準で有意差があることを示す（TukeyのHSD検定）

被覆 3 年目となる2013年の樹冠面温度は，被覆区で高 い傾向が認められた。8月7日，8月15日では，無被覆 区と比べて一番茶被覆区，一番茶二番茶被覆区が有意に 高く，7月30日，8月21日，9月 6 日，10月 4 日では, 無被覆区と一番茶二番茶被覆区との間で有意差が認めら れた。7月23日，8月 2 日，10月10日，10月17日，10月 28日では，処理区間での有意差は認められなかった（図 7 )。

被覆 4 年目となる2014年の樹冠面温度は，被覆区で高 い傾向が認められた。7月25日，7月31日では，無被覆 区と比べて一番茶被覆区，一番茶二番茶被覆区が有意に 高く，7月12日，8月13日，8月19日，9月 2 日では， 無被覆区と一番茶二番茶被覆区との間で有意差が認めら れた。9月11日，9月25日，10月 8 日，10月15日では， 処理区間で有意差は認められなかった（図 8)。

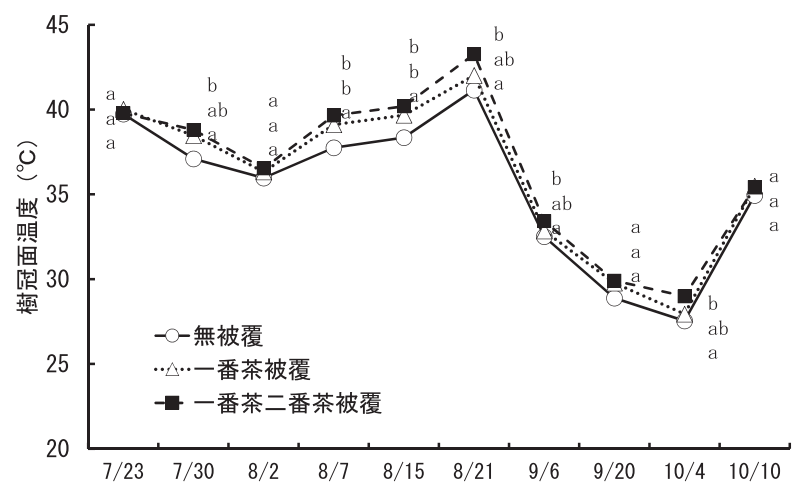

図 7 直がけ被覆処理が2013年（三年目）の樹冠面温度に 及ぼす影響

注：異英文字間で $5 \%$ 水準で有意差があることを示す（TukeyのHSD検定）

\section{5 被覆試験結果の全体的な総括表}

この研究では，5年間にわたって対照を無被覆として 一番茶被覆と一番茶二番茶の連続被覆を比較したので, 結果を総合して概観するため, 棚がけ被覆試験の総括結 果（表10）および直がけ被覆試験の総括結果（表11）に まとめた。これら 2 つの表は, 先に記した3.1〜3.4まで の個別説明を包括的に示している。

\section{4 考察}

被覆が茶樹の生育に及ぼす影響には多くの研究があ り，被覆条件下で伸長する新芽の生育は遮光で抑制され ることは確認されている 数年続けた時の影響, なかでも一番茶期と二番茶期の年 間 2 回の被覆を複数年数続けた場合の影響を無被覆の生 育と比較した研究は行われていない。本試験の結果から, 直がけ被覆した場合には，被覆 2 年目から，一番茶期に 同じ期間被覆した一番茶被覆区，一番茶二番茶被覆区と の間に生育差が認められ，その差は被覆 3 年目にはより 顕著になった（表10）。また，棚がけ被覆した場合には， 被覆 3 年目から，一番茶期に同じ期間被覆した一番茶被 覆区，一番茶二番茶被覆区との間に生育差を認めた（表 11）。加えて, 二番茶摘採後は無被覆条件下で生育した 秋芽でも，それぞれ被覆 2 年目， 3 年目から処理区間に 生育差が認められた。これらの生育の差異は, 同一光環 境条件下で生育した新芽（秋芽）において明らかなよう に，被覆前歴が新芽の生育に影響を及ぼしたためと考え られる。秋芽の生育量は二番茶芽の芽数に影響される ${ }^{16)}$ ため, 二番茶の被覆によって芽数が減少しその影響で秋 芽生育量の減少につながったものと理解される。茶樹で は秋期の新芽の光合成活性は一番茶期, 二番茶期の新芽

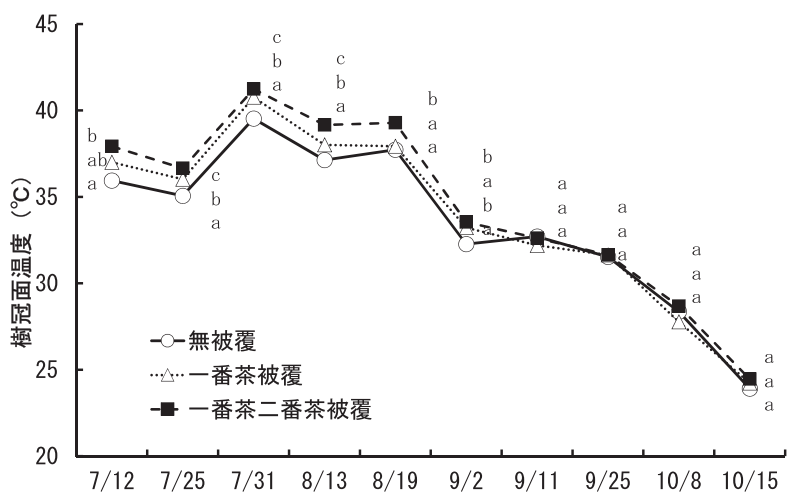

図 8 直がけ被覆処理が2014年（四年目）の樹冠面温度に 及ぼす影響

注：異英文字間で 5 \%水準で有意差があることを示す（TukeyのHSD検定） 
表10 棚がけ被覆の年次による影響程度の総括表

\begin{tabular}{|c|c|c|c|c|c|c|c|c|c|c|c|c|}
\hline 調査項目 & $\begin{array}{c}\text { 2011年 } \\
\text { 夏期 }\end{array}$ & $\begin{array}{c}\text { 2012年 } \\
\text { 夏期 }\end{array}$ & $\begin{array}{c}\text { 2012年 } \\
\text { 秋芽 }\end{array}$ & $\begin{array}{l}\text { 2013年 } \\
\text { 一番茶 }\end{array}$ & $\begin{array}{l}\text { 2013年 } \\
\text { 二番茶 }\end{array}$ & $\begin{array}{c}\text { 2013年 } \\
\text { 夏期 }\end{array}$ & $\begin{array}{c}\text { 2013年 } \\
\text { 秋芽 }\end{array}$ & $\begin{array}{l}\text { 2014年 } \\
\text { 一番茶 }\end{array}$ & $\begin{array}{l}\text { 2014年 } \\
\text { 二番茶 }\end{array}$ & $\begin{array}{c}2014 \text { 年 } \\
\text { 夏期 }\end{array}$ & $\begin{array}{c}\text { 2014年 } \\
\text { 秋芽 }\end{array}$ & $\begin{array}{l}\text { 2015年 } \\
\text { 一番茶 }\end{array}$ \\
\hline 樹冠面温度 & - & - & & & & $\nearrow$ & & & & $\nearrow \nearrow$ & & \\
\hline 新芽長 & & & 一 & 一 & $\checkmark$ & & - & 一 & $\searrow$ & & 一 & 一 \\
\hline 百芽重 & & & $\nearrow$ & - & - & & $\checkmark$ & - & ? & & - & $\checkmark$ \\
\hline 新葉数 & & & $-\nearrow$ & - & $\searrow$ & & $\searrow$ & 一 & $\searrow$ & & - & $-\searrow$ \\
\hline 出開き度 & & & $-\nearrow$ & $\nearrow^{-}$ & $-\nearrow$ & & - & 一 & $\searrow$ & & $-\searrow$ & - \\
\hline 摘芽数 & & & $\searrow \searrow$ & 一 & $\searrow \searrow$ & & $\searrow$ & 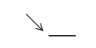 & - & & 一 & - \\
\hline 生葉理論収量 & & & $\searrow \searrow$ & - & $\searrow \searrow$ & & $\searrow$ & 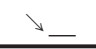 & $?$ & & ? & $\searrow$ \\
\hline ※：参照データ & 図 1 & 図 3 & 表 2 & 表 3 & 表 4 & 図 5 & 表 5 & 表 6 & 表 7 & 図 7 & 表 8 & 表 9 \\
\hline
\end{tabular}

注）表示記号の内容説明

空白：調查データなし

オー: 被覆で高い

一：被覆回数による差が無い

? : 傾向が判然としない

_ $:$ 被覆で低い

二ノ：一番茶二番茶被覆で高い

$\nearrow:$ 被覆回数が多いほど高い

被覆回数が多いほど顕著に高い

: 被覆回数が多いほど低い

๖〉: 被覆回数が多いほど顕著に低い

表11 直がけ被覆の年次による影響程度の総括表

\begin{tabular}{|c|c|c|c|c|c|c|c|c|c|c|c|c|}
\hline 調査項目 & $\begin{array}{c}\text { 2011年 } \\
\text { 夏期 }\end{array}$ & $\begin{array}{c}\text { 2012年 } \\
\text { 夏期 }\end{array}$ & $\begin{array}{c}\text { 2012年 } \\
\text { 秋芽 }\end{array}$ & $\begin{array}{l}\text { 2013年 } \\
\text { 一番茶 }\end{array}$ & $\begin{array}{l}\text { 2013年 } \\
\text { 二番茶 }\end{array}$ & $\begin{array}{c}\text { 2013年 } \\
\text { 夏期 }\end{array}$ & $\begin{array}{c}\text { 2013年 } \\
\text { 秋芽 }\end{array}$ & $\begin{array}{l}\text { 2014年 } \\
\text { 一番茶 }\end{array}$ & $\begin{array}{l}\text { 2014年 } \\
\text { 二番茶 }\end{array}$ & $\begin{array}{c}\text { 2014年 } \\
\text { 夏期 }\end{array}$ & $\begin{array}{c}\text { 2014年 } \\
\text { 秋芽 }\end{array}$ & $\begin{array}{l}\text { 2015年 } \\
\text { 一番茶 }\end{array}$ \\
\hline 樹冠面温度 & - & T & & & & オイ & & & & গイ & & \\
\hline 新芽長 & & & & - & - & & 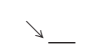 & - & - & & - & $\checkmark$ \\
\hline 百芽重 & & & $-\searrow$ & - & - & & $v_{-}$ & - & - & & - & $-\searrow$ \\
\hline 新葉数 & & & 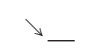 & _ & - & & $-\searrow$ & - & - & & - & $-\searrow$ \\
\hline 出開き度 & & & - & - & $-{ }^{\top}$ & & - & - & - & & - & - \\
\hline 摘芽数 & & & - & - & - & & - & $\checkmark$ & - & & ? & - \\
\hline 生葉理論収量 & & & ${ }_{-}$ & $\searrow$ & \pm & & ${ }_{-}$ & $\searrow$ & - & & \pm & $\searrow \searrow$ \\
\hline ※：参照データ & 図 2 & 図 4 & 表 2 & 表 3 & 表 4 & 図 6 & 表 5 & 表 6 & 表 7 & 図 8 & 表 8 & 表 9 \\
\hline
\end{tabular}

表示記号については表10の注と同じ

より高く ${ }^{17)}$, さらに，一番茶期の新芽の生育には，秋期 から一番茶期直前までに根部に貯蔵されたデンプンが寄

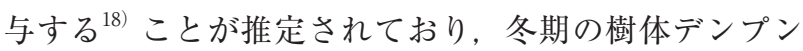
量の低下が一番茶芽の生育量減少につながることも指摘 されているので ${ }^{19)}$, 二番茶を被覆することによって秋芽 の生育量が減少し，秋期および冬期の光合成同化産物生 産能も低下し, 一番茶期の新芽生育量の減少につながっ たと推定される。秋芽生育量の減少とそれによってもた らされる一連の影響によって, 直がけ被覆では 2 年目か ら，また，棚がけ被覆では 3 年目から，有意な差となっ て表れたものと考えられるが，これらの推定を具体的に 裏付けるには被覆茶樹の樹体デンプンの詳細な検討が必 要であり，今後の研究展開を期待したい。

直がけ被覆資材に関する研究では, 資材が直接作物体 に接触することで植物体の温度上昇が認められ，無被覆 と比べて高温になると報告されている20)。茶樹では一番 茶期に直がけ被覆資材の表面が $40^{\circ} \mathrm{C}$ を越える場合を経験 しており, さらに気温が上がりやすい二番茶期には, 被
覆資材の表面温度が $50^{\circ} \mathrm{C}$ を越える場面もあることから， 直がけで被覆した茶樹では, 被覆による弱光に加え高温 の影響も考慮する必要がある。それに対し, 棚がけ被覆 では棚によって被覆資材と茶樹冠面との間には $1 \mathrm{~m}$ 以上 の空間が確保されるので, 茶樹冠面が外気温より高温に なることはなく,弱光が主な生育阻害要因と推定される。 茶樹は, $35^{\circ} \mathrm{C}$ 以上の高温では生育に影響がある ${ }^{21)}$ とさ れることから, より高温になりやすい直がけ被覆では, 高温になりにくい棚がけ被覆と比べて, 生育の低下が一 層現れやすい被覆方法と考えられるが, この試験では両 者を別品種の別圃場で検討しており, 厳密な意味での比 較は困難なため,これ以上の判断は避けたい。

一般に植物体では, 葉温や樹冠面温度は葉面からの蒸 散有無に強く影響され, 蒸散量が多い場合に低下すると され, 街路樹 ${ }^{8 \sim 10)}$ やオウトウ ${ }^{11)}$, チャ ${ }^{12,13)}$ などにおい て蒸散抑制がある場合に葉温が上昇することが示されて いる。本試験で生育低下が認められた被覆処理区では, 被覆年次を重ねるに従い樹冠面温度が有意に高くなる 
傾向性が伺われ，被覆を毎年継続することによって，相 対的に蒸散が抑制される傾向があると考えられる。さし 木段階の研究例ではあるが，盛夏期に遮光率を高くする ほど新根重が減少することも指摘されており ${ }^{22}$, 同様の 現象が成木についても起こる場合があるならば，経年の 被覆による影響によって根部吸収根の生育が悪影響を受 け，蒸散が低下して盛夏期の樹冠面温度が上昇している 可能性も十分考えられる。なお, 本試験では根部生育量 の評価は行っていないので, これらは推論であり今後の 検討が待たれる。これら根部への影響と同様，被覆した 茶樹では成葉の落葉が多くなることは一般に広く経験さ れる現象であり, 被覆が長引くほどその程度も著しいこ とを経験しているため, 葉層と葉の状態そのものが変化 して被覆の影響が顕在化するという可能性についても今 後さらなる検討が必要である。

被覆年次を重ねると，樹体により強く影響する被覆で 茶樹の生育量に差が現れ，夏期の茶樹冠面温度にも明ら かな影響が現れることが確認されたが，その原因の議論 とは別に，茶園の樹冠面温度によって何らかの評価を行 うためには，茶樹冠面温度の差異を安定して検出できる 必要がある。茶樹冠面温度を左右する茶樹の蒸散量は, 天候や環境の影響を受けて刻々と変化している。晴天時 の空気が乾燥する時には蒸散が多く, 曇天や雨天ではき わめて少ない。さらに，12月〜 1 月に最も少なく， 7〜 8 月の盛夏期に最も多い ${ }^{23)}$ 。これらのことから，樹冠面 温度の差異を比較する場合には, 蒸散量が少ない量天時, 雨天時，冬期ではなく，蒸散が盛んに行われている盛夏 期の晴天時がより好ましいと考えられる。本試験では熱 画像計測時の外部環境を極力揃える目的のため, 好適な 観測日を選び, 計測時刻の範囲も明確に定めるとともに, 計測時のカメラ方向や機材を持つ姿勢までなるべく同一 に揃えることを心掛けた。それらの努力をした結果，本 試験では，盛夏期の晴天時に樹冠面温度に $2{ }^{\circ} \mathrm{C}$ 以上の有 意差が認められ，被覆による悪影響が茶樹冠温度にも明 瞭に現れてくることを確認できた。ところが，このこと は同時に，樹冠面温度を茶樹の生育診断に用いるために は，計測する時期や計測の条件がかなり限定されること を示している。従って，現場の茶園で熱画像計測を実用 化するには, 今後さらに一層の検討と改善が必要である。 今のところ熱画像の茶園での活用場面はかなり限定的で あるとしても，熱画像の計測自体は非常に簡便な方法で あり，茶生産場面には茶工場や再生現場などで熱を扱う 場面が多いことや, 熱画像装置の急速な低価格化なども 追い風になり茶生産現場の改善に役立つことを期待した
W。

以上の議論から, 茶樹を従来の倍である年間 2 回被覆 することにより，その悪影響が経年的に蓄積されて生育 量が減少し，さらに直がけ被覆では棚がけ被覆に比べ, 茶樹が高温条件におかれると考えられることから，被覆 の影響がより早く顕在化してくる可能性があることが示 された。また, 盛夏期晴天時の樹冠面温度が, 被覆によ る茶樹の生育低下を検知する手段になりうるという知見 が得られた。

今後, 茶樹の状態診断技術の一層の開発を進めるとと もに，被覆による悪影響を軽減する技術についても診断 結果をもとに検討する必要がある。そのためにも, 被覆 による悪影響をより簡便にとらえる手法を明確にするこ とが重要になる。高度化した画像診断による作物の生理 状態の診断について種々の作物で検討されており ${ }^{24)}$, 茶 樹の状態診断についても今後さらに高度化されるべきも のと考えられる。

\section{5 摘 要}

被覆期間が茶芽の生育に及ぼす影響について 5 年間継 続して調べた。直がけ被覆では，2 年目より，棚がけ被 覆では， 3 年目より，被覆日数が多いほど，翌年の生育 量が減少し, 盛夏期の樹冠面温度も高かった。これらの ことから, 被覆程度の違いが経年的に茶樹生育に影響す ることを明らかにし，夏期の茶樹冠面温度計測により影 響程度を検出できる可能性が示唆された。

\section{6 謝 辞}

本研究の一部は, 農林水産省「農林水産業・食品産業 科学技術研究推進事業 $27015 \mathrm{C}$ 課題名：被覆茶需要に 応える簡易な樹体診断法と効率的被覆作業による高品位 安定生産体系の確立」により行った。

\section{7 引用文献}

1）筞瀬好充・田中静夫 ·青野英也・杉井四郎（1974）：しゃ光の 程度が茶の収量ならびに品質に及ぼす影響．茶技研，No.47， 48-53.

2 ) 忠谷浩司 - 竹若与志一 (2006) : 直がけ被覆期間が一番茶芽の 生育および成分含有率に及ぼす影響，茶研報，No.101，9-16.

3 ）忠谷浩司（2007）：チャの直がけ被覆栽培による品質および収 益性の向上，滋賀農技セ研報 No.46，45～55

4 ）堺田輝貴 - 吉岡哲也 - 中園健太郎 - 仁田原寿一 (2012)：覆い 下栽培における二番茶の高品質・高収益生産のための被覆方 
法. 福岡農総試研報 No.31 63-69.

5 ) 木村泰子・神田真帆 (2013)：本ず被覆内の分光スペクトル特 性と紫外線照射および除去が茶新芽の品質に及ぼす影響。茶 研報, No.116, 1-13.

6 ）青野英也 - 笨瀬好充 - 田中静夫・杉井四郎（1975）：前茶期の 被覆が次茶期の生育に及ぼす影響。茶技研，No.49，1-12.

7 ）滝内基弘・橋本康（1977）：放射温度計による葉温測定と植物 生体情報との関連．計測自動制御学会論文集，No.5，482-488

8 ）大政謙次・田島彰・宮坂佳代子（1990）：サーモグラフィによ る街路樹（仙台市ケヤキ並木）の診断．農業気象，45，271275.

9 ）森本幸裕・武居二郎・ 小南裕志・花山秀文・三輪賢志（1991）: 街路樹ケヤキの活性度診断。日本緑化工学会誌，17，9-15

10）小澤徹三・松本陽介・丹下健・八木久義・長谷川秀三 (2002) : 高速道路緑化における樹木活力調査手法の現状と望まれる要 件. 森林立地，44，45-51.

11）山本隆儀・宮本健一・佐藤嘉一（2005）：熱画像デー夕を用い たオウトウ葉層の光合成光量子フラックス分布㧍よびみかけ の光合成速度分布の同時高速推定. 園学雑, 74, 101-108.

12）松尾喜義・本間知夫 - 細井德夫 - 渡辺利通 (1997)：熱画像 に現れた茶樹の各種ストレス反応. 日本作物学会東海支部会 報 No.123, 19-23.

13）伊地知仁・德田明彦（2017）：熱画像によるチャ樹冠面温度評 価㧍よびその品種間差異と灌水効果. 茶研報, No.123，1-7.

14）廣瀬友二・高橋久光・田邊猛（2002）：遮光処理が茶芽の生育
に及ぼす影響，東農大農学集法 No.47，175-181。

15）神谷仁・米山誠一・若原浩司（2015）：連続した直がけ被 覆がチャの収量㧍よび品質に及ぼす影響。岐阜農技セ研 報 No.15, 1 8.

16）中野敬之・谷博司 - 渡辺直史（1993）：三番茶不摘採園にお ける秋整枝時期が冬芽の生育に及ぼす影響，茶研報，No.78， 47-52.

17）岡野邦夫・松尾喜義（2004）: 茶園表層葉の光合成活性の周年 変化. 茶研報, No.98, 1-9.

18）中山仰 (1972) : 茶樹光合成に関する研究の現状と問題点. 茶 研報, No.37, 1-11.

19）鈴木利和・一家崇志・森田明雄（2013）：冬期の遮光に伴うチ ヤの樹体内炭水化物含量の変動が一番茶新芽の生産性に及ほ す影響. 日作紀, 82，345-352.

20）陳青雲・岡田益己・相原良安（1989）：ベたがけ資材の長波放 射特性と被覆下の正味放射量扮よび葉温について，農業気象， $44,281-286$.

21）関谷直正 - 田中勝夫 - 山下正隆（1979）：茶樹の新芽の生育に 及ぼす気温の影響。茶研報，No.49，11-18。

22）中山仰 (1974）：茶など永年性木本植物のさし木発根と光. 茶 研報, No.41, 1-7.

23）箱瀬好充・田中静夫・青野英也（1971）: 茶園における蒸発散 量の日変化と季節変化．茶研報，No.36，1-11.

24）大政謙次（2002）：プレシジョン・アグリカルチャーのための 画像センシング. 農業情報研究, 11 213-230. 